\title{
Diversity and Disease: The Effects of Coral Diversity on Prevalence and Impacts of Stony Coral Tissue Loss Disease in Saint Thomas, U.S. Virgin Islands
}

\section{OPEN ACCESS}

Edited by:

Lorenzo Alvarez-Filip,

National Autonomous University of Mexico, Mexico

Reviewed by: Valeria Pizarro,

Perry Institute for Marine Science, United States

Craig Dahlgren,

Perry Institute for Marine Science, United States

*Correspondence:

Sophia V. Costa

Sophia.costa@students.uvi.edu

Stephanie J. Hibberts

Stephanie.hibberts@students.uvi.edu

tThese authors have contributed equally to this work

Specialty section: This article was submitted to

Coral Reef Research,

a section of the journal

Frontiers in Marine Science

Received: 19 March 2021

Accepted: 27 May 2021

Published: 28 June 2021

Citation:

Costa SV, Hibberts SJ, Olive DA,

Budd KA, Long AE, Meiling SS, Miller MB, Vaughn KM, Carrión Cl, Cohen MB, Savage AE, Souza MF, Buckley L, Grimes KW, Platenberg R, Smith TB, Blondeau J and Brandt ME

(2021) Diversity and Disease:

The Effects of Coral Diversity on Prevalence and Impacts of Stony Coral Tissue Loss Disease in Saint

Thomas, U.S. Virgin Islands.

Front. Mar. Sci. 8:682688.

doi: 10.3389/fmars.2021.682688
Sophia V. Costa ${ }^{1 *}$, Stephanie J. Hibberts ${ }^{1 *}$, Danielle A. Olive ${ }^{1,2}$, Kayla A. Budd ${ }^{1 \dagger}$, Alexys E. Long ${ }^{1 t}$, Sonora S. Meiling ${ }^{1+}$, Madyson B. Miller ${ }^{1+}$, Kelsey M. Vaughn ${ }^{1+}$, Claudia I. Carrión', Maksym B. Cohen'1, Annie E. Savage1, Matthew F. Souza1, Lorraine Buckley ${ }^{1}$, Kristin W. Grimes ${ }^{1}$, Renata Platenberg ${ }^{1}$, Tyler B. Smith ${ }^{1}$, Jeremiah Blondeau ${ }^{3}$ and Marilyn E. Brandt ${ }^{1}$

1 Center for Marine and Environmental Science, University of the Virgin Islands, St. Thomas, VI, United States, ${ }^{2}$ Division of Fish and Wildlife, Government of the U.S. Virgin Islands, St. Thomas, VI, United States, ${ }^{3}$ NOAA Southeast Fisheries Science Center, Coral Gables, FL, United States

Stony coral tissue loss disease (SCTLD) was first observed in St. Thomas, U.S. Virgin Islands (USVI) in January 2019. This disease affects at least 20 scleractinian coral species; however, it is not well understood how reef diversity affects its spread or its impacts on reef ecosystems. With a large number of susceptible species, SCTLD may not follow the diversity-disease hypothesis, which proposes that high species diversity is negatively correlated with disease prevalence. Instead, SCTLD may have a higher prevalence and a greater impact on reefs with higher coral diversity. To test this, in 2020 we resampled 54 sites around St. Thomas previously surveyed in 2017 or 2019 by the National Oceanic and Atmospheric Administration National Coral Reef Monitoring Program. These sites represented a variety of species diversity values [categorized into poor ( $<12$ spp. rich.) and rich ( $\geq 12$ spp. rich.)] in multiple disease zones (Endemic: disease present $\geq 9$ months; Epidemic: disease present 2-6 months; Control and Emergent: disease present no disease/ $<2$ months). We hypothesized that, contrary to the diversity-disease hypothesis, sites with high species diversity (as measured by species richness or Simpson's index) would have higher disease prevalence within the epidemic zone, and that high species diversity sites would have a greater impact from disease within the endemic zone. Results indicated a significant positive relationship between disease prevalence and diversity in the epidemic zone, and a similar trend in the endemic zones. Additionally, a negative relationship was seen between pre-outbreak diversity and loss of diversity and coral cover within the endemic zone. This supports the hypothesis that higher diversity predicts greater disease impact and suggests that SCTLD does not follow the diversity-disease hypothesis. Within the epidemic zone, the species with the highest SCTLD prevalence were Dendrogyra cylindrus, Colpophyllia natans, and Meandrina meandrites, while in the endemic zone, Diploria labyrinthiformis, Pseudodiploria strigosa, Montastraea cavernosa, and Siderastrea siderea had the 
highest SCTLD prevalence. Understanding the relationship between species diversity and SCTLD will help managers predict the most vulnerable reefs, which should be prioritized within the USVI and greater Caribbean region.

Keywords: stony coral tissue loss disease, US Virgin Islands, coral disease, diversity, impacts, reef ecosystems

\section{INTRODUCTION}

Devastating impacts of coral diseases on Caribbean reef ecosystems are well documented and have led to drastic alterations in community composition and diversity within reef communities (Aronson and Precht, 2001; Ward et al., 2006; Miller et al., 2009; Pollock et al., 2011; Alvarez-Filip et al., 2019). The Caribbean region has been identified as a "hotspot" for coral disease due to the high number of diseases and high frequency of outbreaks (Sutherland et al., 2004; Weil and Rogers, 2011; Muller and van Woesik, 2012). Only $8 \%$ of all coral reef species are found in the Caribbean, yet $66 \%$ of all coral diseases occur within this region (Green and Bruckner, 2000; Muller and van Woesik, 2012). A 3-year (2005-2007) study by Ruiz-Moreno et al. (2012) found that $20 \%$ of Caribbean reefs had disease prevalence of over $10 \%$. With a high number of disease events, reefs within the Caribbean have seen a decline in living corals from 50 to $80 \%$ (Aronson and Precht, 2001; Jackson et al., 2014; Alvarez-Filip et al., 2019). However, disease events can be especially destructive when it targets critical reef-building species.

Stony coral tissue loss disease (SCTLD) emerged in 2014 off the coast of Miami, Florida; this coincided with both the 20142015 coral bleaching event and the dredging of the Port of Miami from 2013 to 2015, which subsequently led to increased sedimentation and poor water quality (Precht et al., 2016; Miller et al., 2016; Walton et al., 2018; Gintert et al., 2019). SCTLD was first described as a white-plague disease with acute tissue loss (Precht et al., 2016). It is now identified by lesions that may appear in the middle of a colony and are greater than $1 \mathrm{~cm}$ wide (SCTLD Case Definition, 2018; Virgin Islands Coral Disease Advisory Committee VI-CDAC, 2020). SCTLD affects at least 20 scleractinian species in a specific hierarchy (SCTLD Case Definition, 2018). However, more data is needed to determine the susceptibility of all scleractinian species susceptibility within the greater Caribbean region. Since SCTLD affects critical reef building coral species, its influence greatly impacts reef composition and structure. For example, in Florida from 2014 to 2017 , SCTLD led to a $30 \%$ decrease in regional coral density and a $60 \%$ decrease in live coral tissue cover (Walton et al., 2018).

In January 2018, SCTLD was reported in the Gulf of Mexico and has since rapidly spread across the Caribbean (AlvarezFilip et al., 2019; Kramer et al., 2020). Although not confirmed, evidence suggests that SCTLD first arrived in St. Thomas via ballast water from ships and that its subsequent spread is associated with local currents and tidal patterns (Dahlgren, 2020; Staletovich, 2020). Observations of disease in the U.S. Virgin Islands (USVI) were first reported in January 2019 off the southern coast of St. Thomas (Virgin Islands Coral Disease Advisory Committee VI-CDAC, 2020; Kramer et al., 2020). These observations were soon confirmed as SCTLD being that they followed the disease trends (Virgin Islands Coral Disease Advisory Committee VI-CDAC, 2020). The disease advanced from its point of origin, Flat Cay, toward St. John, USVI (Virgin Islands Coral Disease Advisory Committee VI-CDAC, 2020). However, the relationship between coral community structure and disease prevalence, as well as the effects of the disease, have yet to be determined.

The diversity-disease hypothesis, also referred to as the dilution effect (Keesing et al., 2006; Huang et al., 2016), describes the relationship between community structure and disease across global systems, including coastal, terrestrial, and marine (Gilbert and Sousa, 2002; Mitchell et al., 2002; Keesing et al., 2006; Civitello et al., 2015). This theory suggests that increased species diversity reduces disease risk (Keesing et al., 2006). Therefore, systems with higher species diversity have reduced disease prevalence compared to their less diverse counterparts (Keesing et al., 2006). The opposite of this effect is referred to as the amplification effect, when increased species diversity increases disease risk (Keesing et al., 2006). The diversity-disease hypothesis is supported in some coral reef diseases; ecosystems with low species diversity are more susceptible to diseases with specialist pathogens (Aeby et al., 2011). For example, Acropora white syndrome was more prevalent in locations with lower species diversity (Aeby et al., 2011). In contrast, Ward et al. (2006) found no significant relationship between scleractinian coral diseases (black band disease, dark spot disease, yellow band/blotch, white pox, white band, and white plague) and species richness in Mexico. In southeastern Florida, Walton et al. (2018) found major declines in density and diversity in areas with higher disease prevalence, especially those with reef-building species. It is unknown if SCTLD follows either the diversitydisease hypothesis or the amplification effect, although, a recent study by Muller et al. (2020) suggests that SCTLD may not follow the diversity-disease hypothesis. Spatial epidemiology revealed SCTLD was present more often in sites with higher density and diversity when SCTLD first emerged in southern Florida (Muller et al., 2020). This may indicate that the causative agent of SCTLD is a host generalist pathogen. However, this hypothesis has not been tested in other areas of the Caribbean to determine if SCTLD follows similar trends throughout the region. To better understand the disease, it is necessary to understand which reefs are most susceptible, in addition to quantifying the ecological consequences of SCTLD.

Identifying a species' susceptibility to SCTLD could determine the vulnerability of a species to the disease, and which reefs will be most impacted based on species composition. However, species susceptibility could exhibit spatial differences that may vary regionally (SCTLD Case Definition, 2018; Aeby et al., 2019). For example, a study by the Florida Keys National Marine Sanctuary (SCTLD Case Definition, 2018) determined that 
Agaaricia agaricites and Porites astreoides were intermediately susceptible to SCTLD based on mortality rate over time, however, Alvarez-Filip et al. (2019) determined these species had low susceptibility based on disease prevalence over time in Mexico. Due to the severity of this disease, it is critical to know the susceptibility of species in each region of the Caribbean to better understand the impacts of SCTLD.

In this study, we were interested in understanding the active epidemiology and ecological consequences of SCTLD within the USVI as it relates to the diversity-disease hypothesis. We expected that disease prevalence within the epidemic zone (2-6 months post-disease emergence) would be greater at highly diverse sites than at sites with low coral species diversity. Disease incidence at species-rich and poor sites within disease-impacted zones were compared to understand the relationship between disease and diversity. It was also hypothesized that within the endemic zone (disease present for $>9$ months) highly diverse sites would undergo the greatest community and ecological changes due to SCTLD. Understanding how SCTLD changes coral community structure can help resource managers respond to this disease as it spreads and emerges throughout the USVI and greater Caribbean region.

\section{MATERIALS AND METHODS}

\section{Site Selection}

A stratified random sampling design was used to select sites from the National Oceanic and Atmospheric Administration (NOAA) National Coral Reef Monitoring Program (NCRMP). Sites were previously sampled in either 2017 ( $n=233$ in northern USVI) or 2019 ( $n=232$ in northern USVI) and were selected and coded for this study based on species richness (poor: $<12$ spp. and rich: $\geq 12$ spp., cut off based on natural break), as well as location relative to the known progression of SCTLD (Figure 1). A total of 54 sites (42 from 2017 and 12 from 2019) around St. Thomas were resampled and categorized as one of four disease sites: control, emergent, epidemic, or endemic (Figure 1). Each zone was intended to demonstrate the relationship between disease prevalence and coral diversity, as well as the impacts of SCTLD across differing time frames. Control sites were defined as areas where SCTLD was not observed during surveys in this study and were within a geographic area considered to be clear of SCTLD by the VI-CDAC through previous site surveillance. Emergent sites were defined as areas where SCTLD was present at the site for less than 2 months but not documented within sampling transects. Epidemic sites were defined as those within the geographic area known to be affected by SCTLD for at least 2 months but less than 6 months, and endemic sites were defined as reefs within the geographic area known to be affected by SCTLD for 9 months or longer. Control and emergent sites were combined into one zone and analyzed to quantify potential changes to coral community structure unrelated to SCTLD (e.g., the passage of major Hurricanes Irma and Maria within 100 kilometers of the study sites in September 2017). Sites were categorized by disease zone and diversity (control/species-rich, control/species-poor, emergent/species-rich, emergent/species- poor, epidemic/species-rich, epidemic/species-poor, endemic/ species-rich, endemic/species-poor; Figure 1).

\section{Data Collection}

Data collection occurred from January to June of 2020. Global Positioning System (GPS) coordinates were used to navigate to the previous NCRMP site locations for resampling. Sampling methodology followed established NOAA NCRMP protocols National Centers for Coastal Ocean Science (NCCOS) and Southeast Fisheries Science Center (SEFSC), 2018, 2020 on community structure, with benthic divers using the line point intercept (LPI) technique and coral demographic divers assessing corals within a belt transect. At each location, surveys lasted a maximum of $30 \mathrm{~min}$ and were initiated by attaching a transect tape to a non-living structure and swimming $15 \mathrm{~m}$ in a random direction.

The benthic diver used a line point intercept methodology to record the benthic cover category directly under the transect tape every $15 \mathrm{~cm}(n=100)$. The coral demographic diver surveyed all scleractinian corals within a belt transect extending $1 \mathrm{~m}$ to the left of the transect tape for $10 \mathrm{~m}$. All adult coral colonies $(\geq 4 \mathrm{~cm}$ ) were identified to species level. Disease was identified using modified NCRMP classifications with "present" indicating SCTLD present on the coral, "fast" indicating likely SCTLD cases but could be another Acute Tissue Loss Disease (ATL), "slow" indicating diseases other than ATL diseases, and "absent" indicating no disease present on the coral. Hereafter, we have used ATL to refer to the combination of confirmed and likely SCTLD cases ("fast" and "present"). Identification of SCTLD was documented when one or more disease lesions, especially when not originating from the colony base, exceeded $1 \mathrm{~cm}$ maximum width, suggesting rapid progression (Supplementary Figure 1). If the maximum dive time was reached before either the demographic belt transect or benthic survey was completed, divers completed surveying to the nearest whole meter along the transect.

\section{Data Analyses}

Using the NOAA NCRMP database, species were grouped for diversity measurements according to Smith et al. (2013) protocols (i.e., grouping of Agaricia, Orbicella, and Porites families). Species richness and Simpson's Diversity Index (collectively referred to as species diversity metrics), as well as coral density were calculated for each site using the coral demographic data collected in 2017 or 2019 (pre-outbreak) and data collected for this study in 2020. Coral density (\# of corals $/ \mathrm{m}^{2}$ ) was calculated by dividing the total number of corals surveyed in the transect by the demographic survey $\mathrm{m}^{2}$ completed. Using the demographic data, the prevalence (\%) of all ATL ("present" and "fast") and prevalence (\%) of SCTLD ("present") was calculated by dividing the total number of diseased corals by the total number of corals assessed in each transect. Coral cover (\%) was calculated for each year from the benthic data by dividing the total number of points identified as stony corals by the total number of points assessed on the benthic transect (i.e., \# coral points/100). Proportional change in all metrics was calculated by subtracting 2020 values from pre-outbreak values 


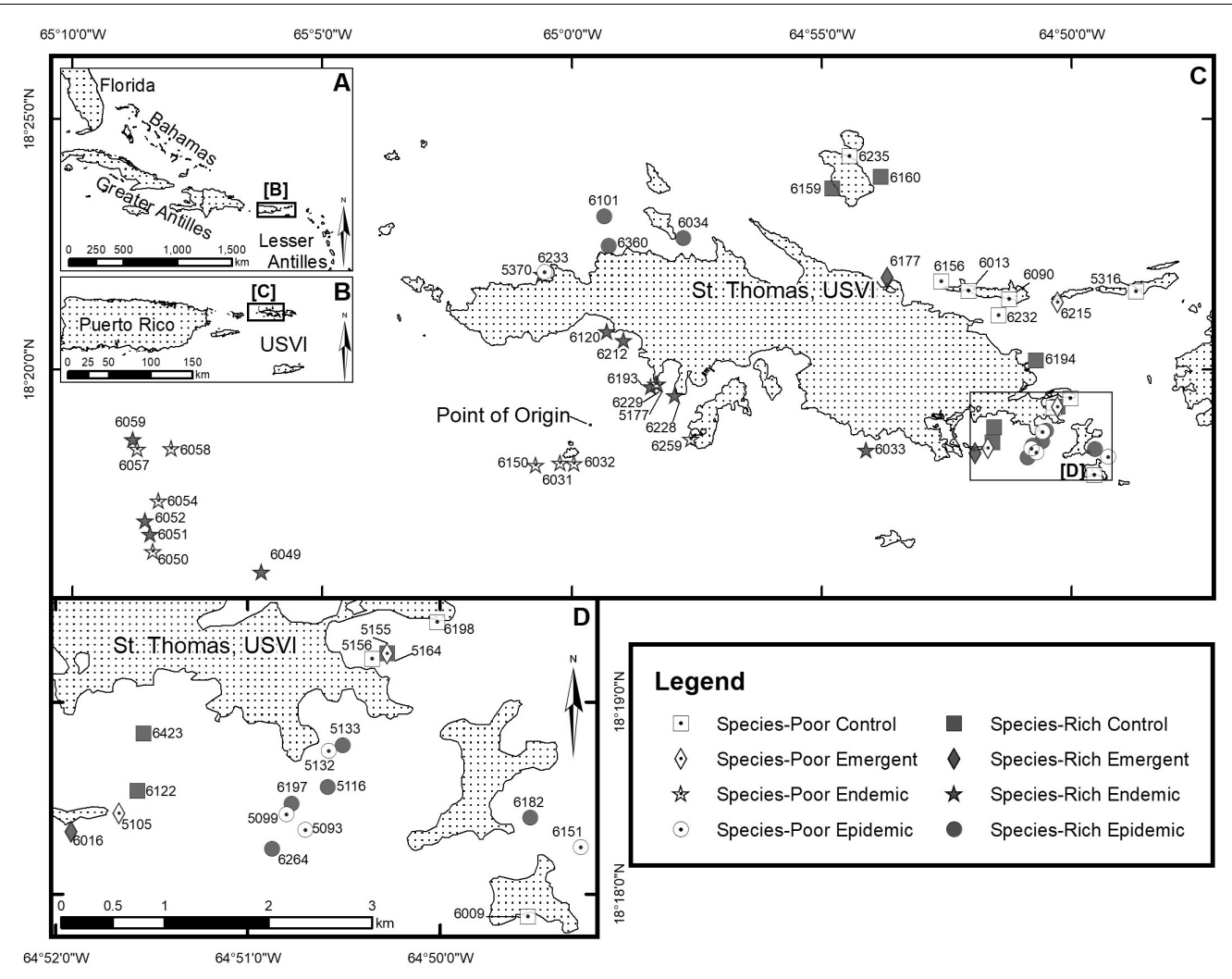

FIGURE 1 | 2020 study sites in St. Thomas, USVI shown in the (A) Caribbean Region, (B) Virgin Islands subregion, (C) study sites around St. Thomas, and (D) study sites in the SE of St. Thomas. Sites are labeled with the NCRMP site number, with the first number representing the year of initial survey $(6 x x x=2017$, $5 x x x=2019$ ). Point of origin is labeled.

then dividing by the pre-outbreak value. This measurement was used to assess change while controlling for pre-outbreak variability in site characteristics to better assess disease impact. For each zone, the standard error of the mean was calculated using 2020 data by dividing the standard deviation of each zone (control, emergent, epidemic, and endemic) by the square root of the number of sites.

Surveys with less than 15 coral colonies (i.e., sites 6,013, 6,194, $6,196,6,235,6,009,6,052,6,150$, and 6,151) were removed from statistical analyses using coral demographic data, although data from benthic surveys at these sites were analyzed. Sites 6,032, $6,215,6,228$, and 6,229 were difficult to access by boat, making it unclear whether the same GPS locations were resampled. Data from these sites were not used in the analysis between pre-outbreak and 2020 values (Figure 1).

Statistics were conducted in R-Studio version 3.6.2 ( $R$ Core Team, 2019). The 2020 ATL prevalence and change in coral density did not meet assumptions of normality and homoscedasticity, and a Kruskal-Wallace and a post hoc Dunn's Multiple Comparisons test were performed to compare disease prevalence and change in coral density by zone (endemic vs. epidemic). Analysis of Variance (ANOVAs) tests were used to examine changes in coral cover, richness, and Simpson's Diversity index among zones. Linear and quadratic regressions were performed for both epidemic and endemic zones to examine the relationship between ATL disease prevalence and diversity (pre-outbreak and 2020). To understand the impacts of SCTLD, linear regressions were performed to evaluate the relationships between coral cover, coral density, and the diversity metrics and proportional change in the endemic, epidemic, and combined control and emergent zones.

The average relative abundance of each species was calculated within all sites pooled, species-poor sites only, and speciesrich sites only in each zone (epidemic, endemic, and control and emergent). This was calculated by dividing the number of corals of each species by the total number of corals in each respective site (species-poor sites, species-rich sites, or both sites in each zone). The average relative abundance of each species was then used to create a non-metric multidimensional scaling (nMDS) ordination to determine dissimilarity between pre-outbreak and 2020 coral community composition (presence/absence of observed species) within each zone. An Analysis of Similarity (ANOSIM) was then performed to identify similarity between pre-outbreak and 2020 coral community composition data.

Species-specific disease prevalence was calculated for both epidemic and endemic zones by dividing the number of corals of a species identified with disease "present" by the total number of corals of that species assessed in each respective zone. Based on SCTLD disease prevalence within the epidemic zone, species were 


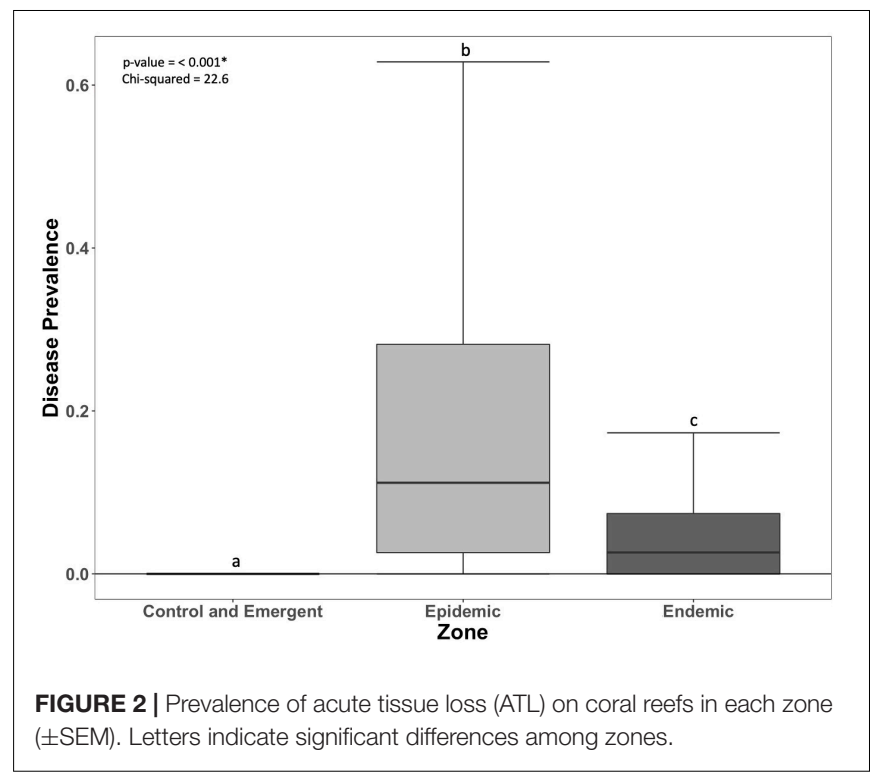

classified as high (>40\%), intermediate (20-40\%), low (0-19.9\%), or unknown (no data recorded). Confidence in our susceptibility classification was determined using the sample size and disease prevalence of each species (Supplementary Table 1). Changes in community composition were recorded as the absolute gain, loss, or stasis of an individual coral species between pre-outbreak and 2020 values.

\section{RESULTS}

\section{Changes Among Zones}

Acute tissue loss (ATL) prevalence was significantly greater in the epidemic zone than in the endemic zone; there was little occurrence of SCTLD in the control and emergent zone (Figure 2). There was no significant relationship of ATL prevalence for species code (species-rich or species-poor) nor the interaction of species code and zones (Supplementary Table 2). There were no significant differences in change in coral cover, density, species richness, or Simpson's Diversity Index among zones (Figure 3).

\section{Disease and Diversity}

Higher disease prevalence was seen at more diverse sites in the endemic zone, but this relationship was not significant (Figure 4). Disease prevalence and the Simpson's Diversity Index had both a significant positive quadratic and linear relationship in the epidemic zone ( $p<0.001,0.0255$, respectively, Figure 4); the shape of the relationship was driven by a single low diversity point.

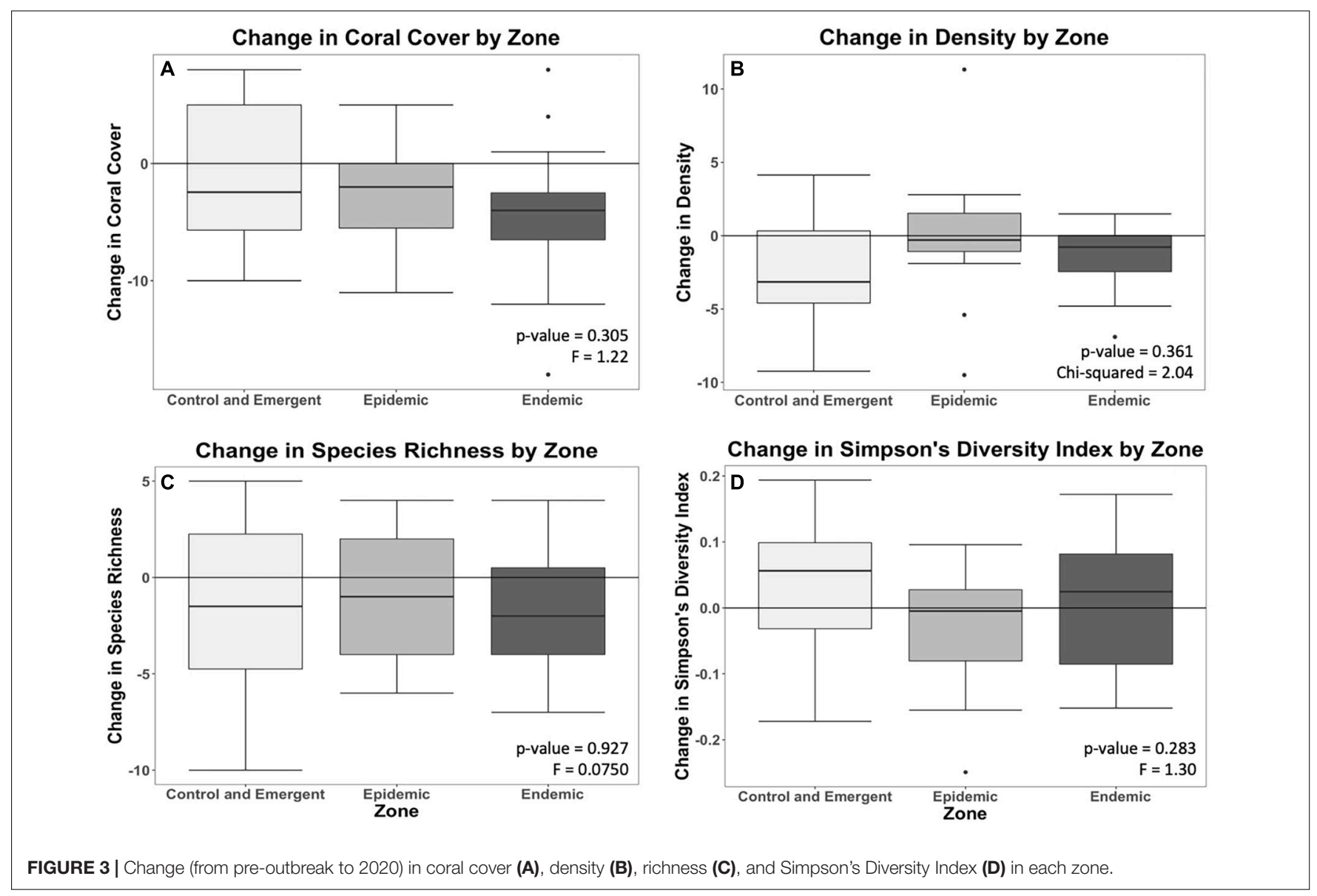



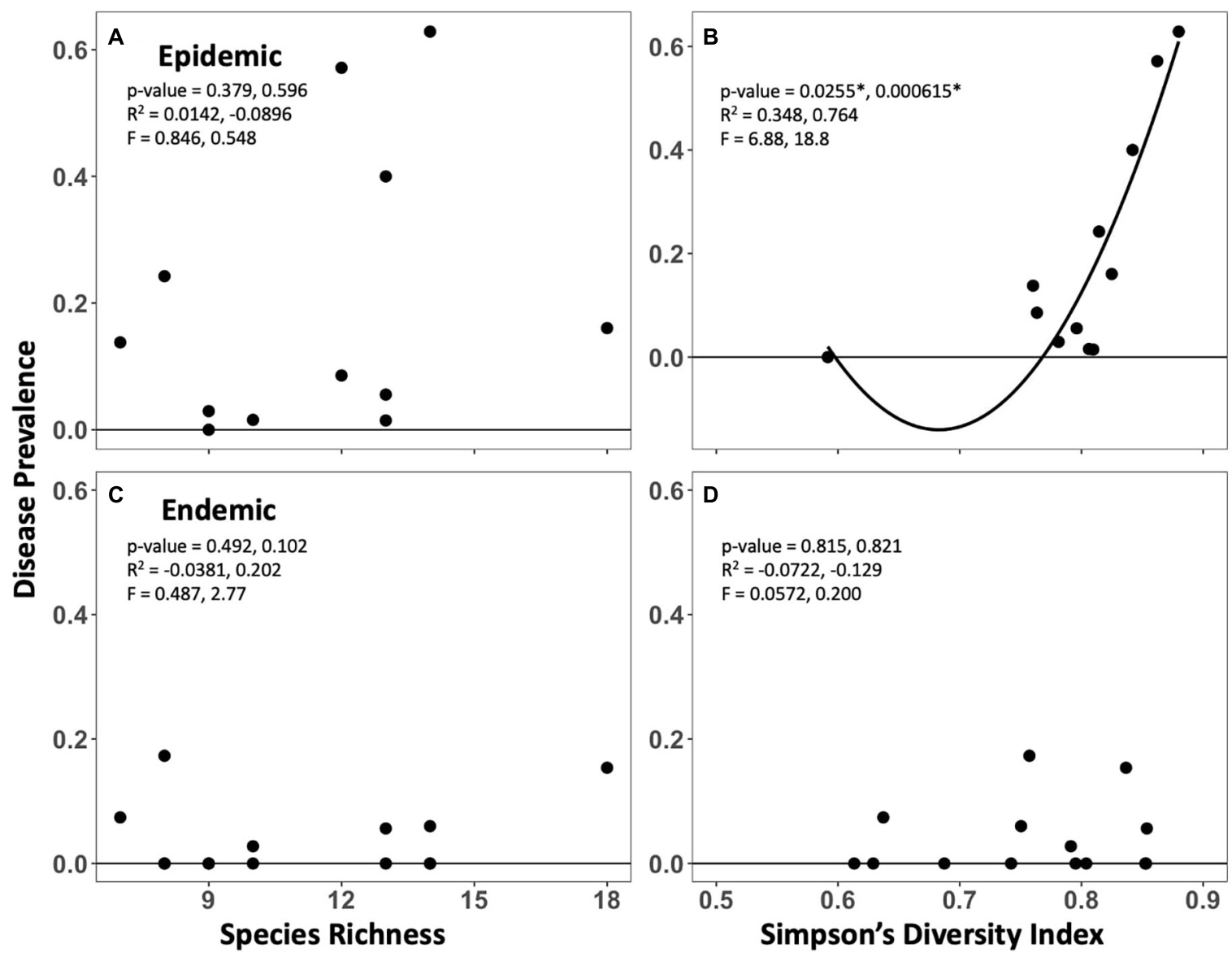

FIGURE 4 | Relationships between disease prevalence (2020) and pre-outbreak species richness (A,C) and Simpson's Diversity Index (B,D) within the epidemic (top) and endemic (bottom) zones. Primary values reported are for a linear relationship, secondary values are for the shown quadratic relationship.

\section{Impacts of Stony Coral Tissue Loss Disease}

Results demonstrate that more diverse sites experienced increased loss of diversity but less loss of coral cover. There were significant negative relationships between pre-outbreak diversity metrics (species richness and Simpson's) and their respective change between pre-outbreak and 2020 surveys (Figure 5). In the endemic zone, there was a significant positive relationship between pre-outbreak Simpson's diversity index and proportional change in coral cover (Figure 6). In other words, sites that were initially more diverse showed less proportional change in coral cover by 2020. There were no significant relationships between change in coral cover and either pre-outbreak coral cover or pre-outbreak species richness (Supplementary Figure 2). There were no significant relationships between proportional change in density and any metric (Supplementary Figure 3).

Various species led the change in coral cover at rich and poor sites within the endemic zone, with more rare species lost at the rich sites. Less diverse sites within the endemic zone saw more loss in coral cover (Figure 6). This change in coral cover was driven by the loss of Orbicella spp., Agaricia spp., Dichocoenia stokesii, Meandrina spp., Montastraea cavernosa, and Siderastrea spp. (Figure 7). The loss of coral cover at species-rich endemic sites was observed in Orbicella spp. and Agaricia spp., but also more rare species like Colpophyllia natans, Dendrogyra cylindrus, and Madracis spp. (Figure 7). In the endemic zone, species- poor sites had a higher percentage of highly susceptible species (19\%) than species-rich sites (13\%; Figure 8). The species-rich sites had higher relative amounts of species of unknown susceptibility (14\%), compared to the poor sites (2\%; Figure 8). Despite changes in coral diversity and abundance, there were no detectable changes in overall coral community structure within any zone through time (ANOSIM: control zone $R=-0.026, p=0.722$; epidemic zone $R=-0.064, p=0.894$; endemic zone $R=0.01, p=0.309$; Supplementary Figure 4).

\section{Susceptibility}

The prevalence of SCTLD varied for each coral species surveyed in the epidemic and endemic zones (Table 1). The species with the highest SCTLD prevalence in the epidemic zone were Dendrogyra cylindrus (100\%), Colpophyllia natans (86\%), and Meandrina meandrites (80\%). The species with the highest SCTLD prevalence in the endemic zone were Diploria 

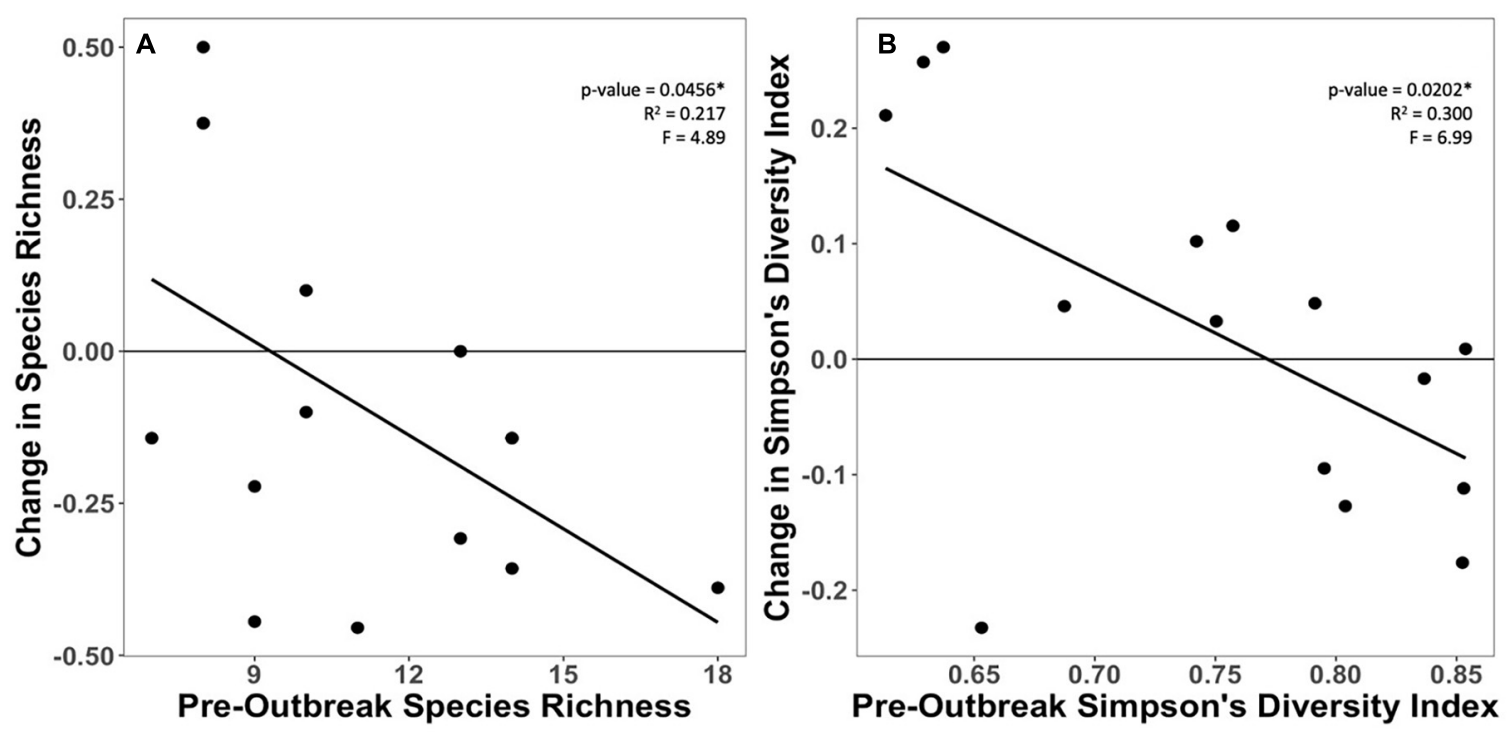

FIGURE 5 | Relationship between pre-outbreak (A) species richness and (B) Simpson's diversity, and each metric's respective proportional change in the endemic zone.

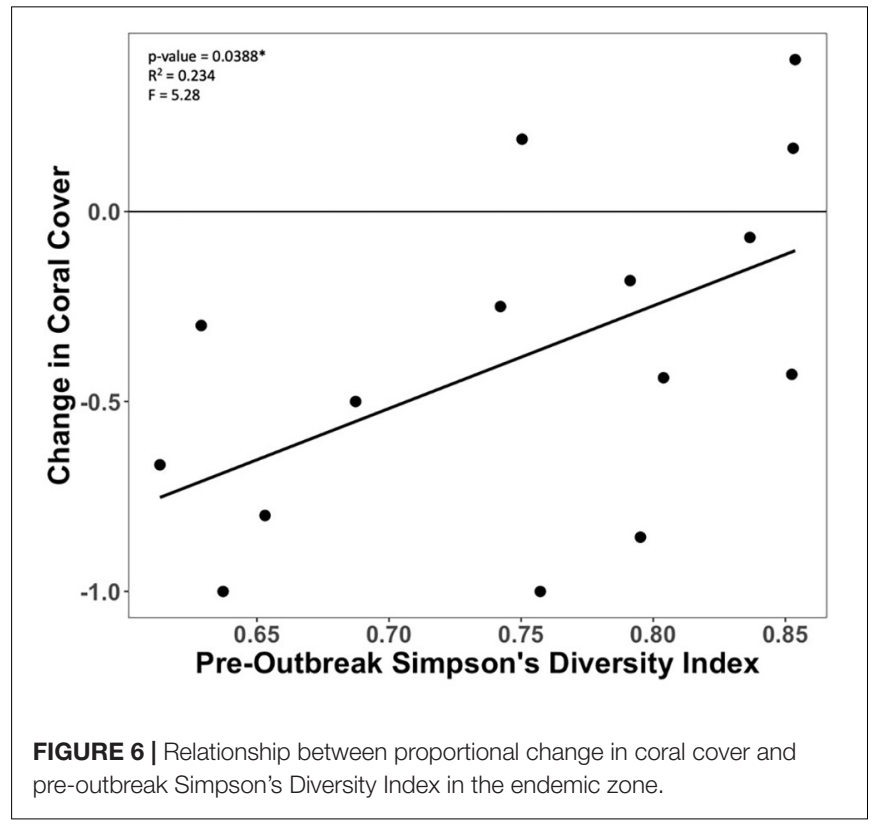

labyrinthiformis (100\%), Montastraea cavernosa (23\%), and Siderastrea siderea (20\%). In the combined epidemic and endemic zones Diploria labyrinthiformis (75\%), Colpophyllia natans (67\%), Dendrogyra cylindrus (67\%), and Meandrina meandrites (67\%) had the highest disease prevalence.

Changes in community composition of each susceptibility classification were observed in every zone. In both the epidemic zone as well as the control and emergent zone, the percent of species for which susceptibility had not been previously described (unknown susceptibility) decreased from pre-outbreak to 2020 (Figure 9). The endemic zone had an increase of 3-5\% species of unknown susceptibility. Species of high susceptibility increased in the control and emergent zone from pre outbreak to 2020, while in the epidemic and endemic zones, it decreased (Figure 9). The greatest loss of species with high susceptibility was seen in the endemic zone (6-3\%). Percent of species with low susceptibility increased in both the epidemic and endemic zones from preoutbreak to 2020 while it decreased in the control and emergent zone (Figure 9).

\section{DISCUSSION}

\section{Control and Emergent}

Other disturbances occurred between the 2017 and 2019 baseline assessment and the assessment of SCTLD impacts in 2020. There were significant losses of density and species richness, but not coral cover, within the control and emergent zone that were likely due to hurricane damage and bleaching (Supplementary Figures 5, 6). In September 2017, after the NCRMP surveys, Hurricanes Irma and Maria, both category 5 hurricanes, passed over the USVI. The eye of Hurricane Irma passed $32 \mathrm{~km}$ to the north of St. Thomas (Gochfield et al., 2020) nearest to the control and emergent zone; the endemic and epidemic zones were further from the storms and largely on the southern side of St. Thomas, which was more sheltered. While the Territorial Coral Reef Monitoring Program (TCRMP) reported significant fragmentation and dislodging of coral colonies after these storms, there was minimal change in coral cover (Smith et al., 2017). Further potential impacts to coral cover and diversity include the 2019 bleaching event, which occurred after the pre-outbreak 2017 and 2019 NCRMP surveys (Noaa Coral Reef Watch., 2020; Supplementary Table 3). Species that are highly susceptible to bleaching in the 


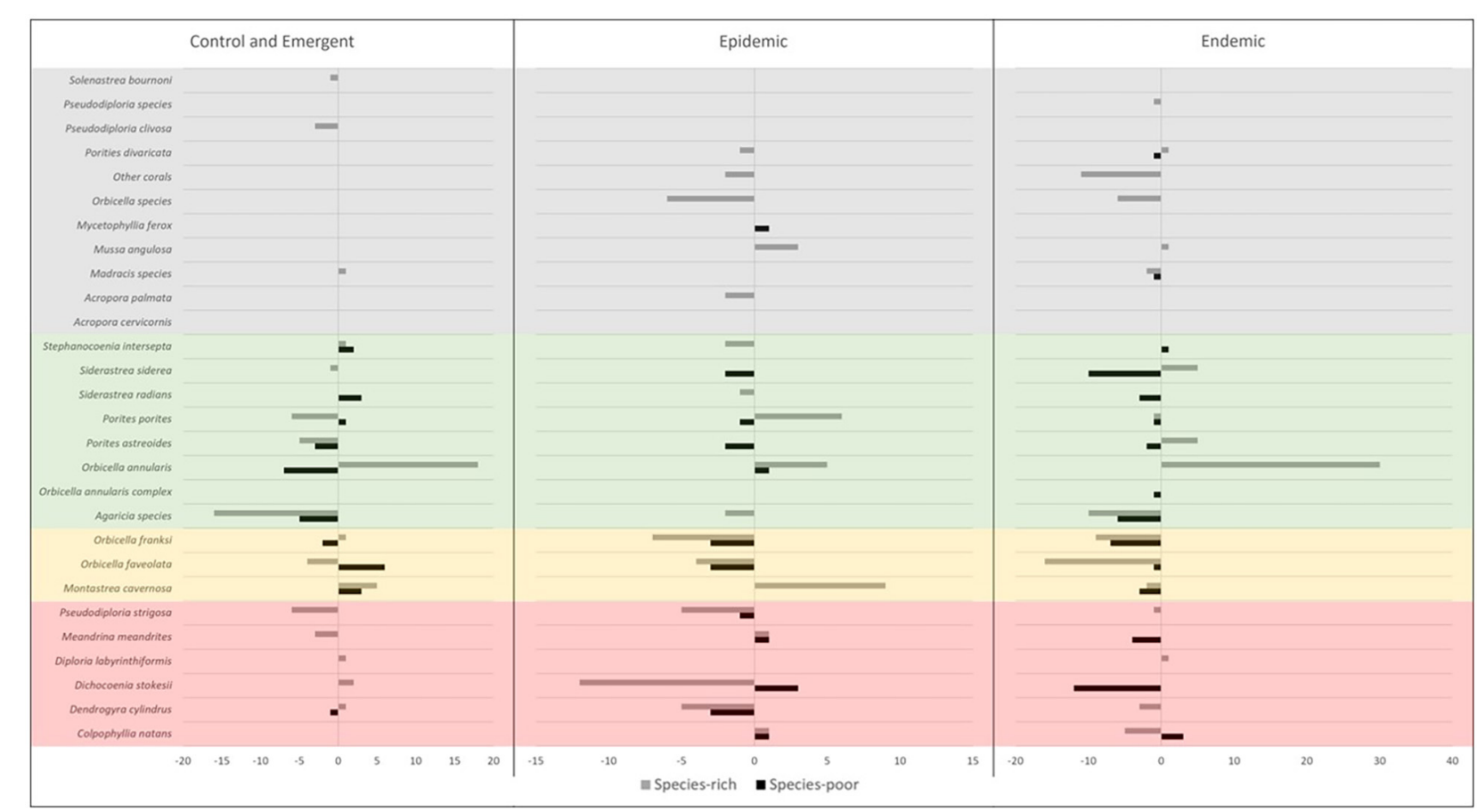

FIGURE 7 | Absolute change in coral cover between pre- and post- outbreak surveys for each species at species-rich ( $\geq 12$ spp.) and species-poor ( $<12$ spp.) sites by zone. Species susceptibility classifications are shown in the color boxes and based on the results of this study (Red = high susceptibility, Yellow $=$ intermediate susceptibility, Green = low susceptibility, Gray = unknown susceptibility).

USVI include Agaricia spp., Colpophyllia natans, and Orbicella species complex (Smith et al., 2013). These species made up approximately $30 \%$ of the control and emergent sites in the pre-outbreak surveys. Due to variance in susceptibility to hurricanes and bleaching, some changes in density and species richness were observed, but not coral cover, within the control and emergent zone between pre- (2017 and 2019) and postoutbreak (2020) surveys.

\section{Diversity-Disease Hypothesis}

The relationship between diversity and disease prevalence seen in both the endemic and epidemic zones suggests that SCTLD does not follow the diversity-disease hypothesis. Trends of higher disease prevalence found at more diverse sites (Figure 4) was likely caused by SCTLD affecting numerous coral species ( $>20$; SCTLD Case Definition, 2018). This study found that 17 of 23 species were affected within the epidemic zone around St. Thomas, USVI (Table 1). This indicates that SCTLD may behave like a host-generalist pathogen, which would affect more species-rich environments than a host-specific pathogen (Keesing et al., 2006; Haas et al., 2011). Additionally, this suggests that SCTLD may demonstrate an amplification effect, likely through an increased encounter rate between the pathogen and susceptible species (Keesing et al., 2006). Our findings coincide with the concurrent study by Muller et al. (2020) that suggested that SCTLD does not follow the diversity-disease hypothesis in Florida.

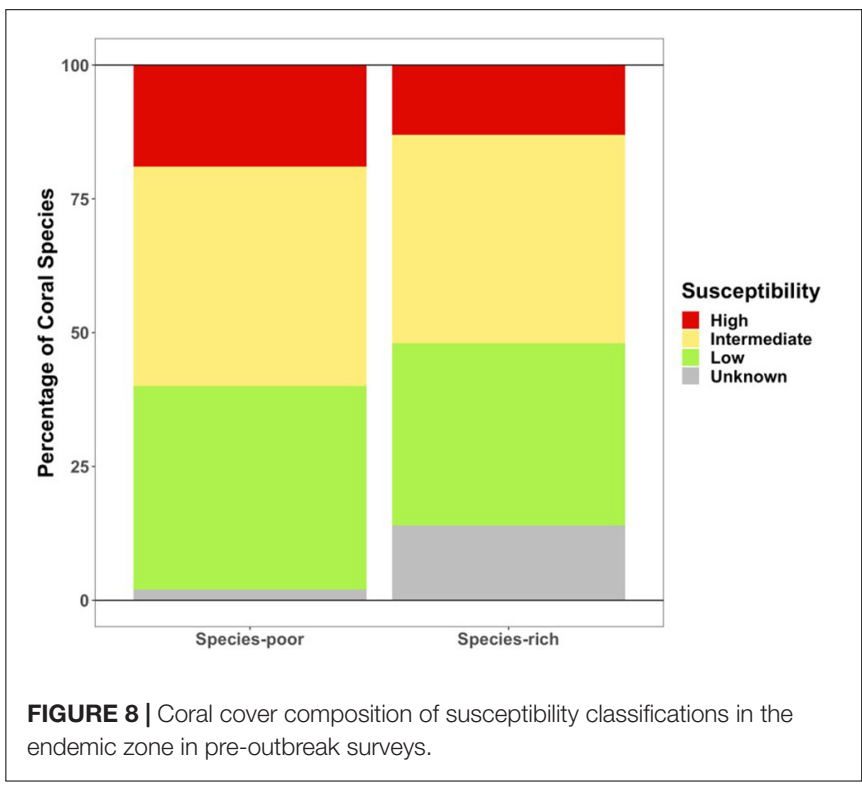

More significant positive relationships between disease prevalence and diversity may not have been detected because of variation in the lengths of time that sites were affected with SCTLD. Epidemic zone sites were affected from anywhere between 2 and 6 months, resulting in a range of severity and spread of disease at sites. A monitoring study in the Middle Florida Keys first reported SCTLD in March of 2018, 
TABLE 1 | Coral species disease prevalence by zone and comparison of species susceptibility in Florida (FL), United States (SCTLD Case Definition, 2018) and this study in St. Thomas (STT), USVI.

\begin{tabular}{|c|c|c|c|c|c|c|c|c|c|c|c|}
\hline \multirow[b]{2}{*}{ Species } & \multicolumn{2}{|c|}{ Susceptibility } & \multicolumn{3}{|c|}{ Epidemic zone } & \multicolumn{3}{|c|}{ Endemic zone } & \multicolumn{3}{|c|}{ Epidemic and endemic } \\
\hline & FL & STT & No. of corals & Affected corals & Disease prev. & Number of corals & Affected corals & Disease prev. & No. of corals & Affected corals & Disease prev. \\
\hline Agaricia agaricites & $\mathrm{U}$ & I & $38(7 \%)$ & 14 & $37 \%$ & $73(8 \%)$ & 1 & $1 \%$ & $111(8 \%)$ & 15 & $14 \%$ \\
\hline Agaricia fragilis & $U$ & L & $1(0 \%)$ & 0 & $0 \%$ & $4(0 \%)$ & 0 & $0 \%$ & $5(0 \%)$ & 0 & $0 \%$ \\
\hline Agaricia grahamae & $u$ & $u$ & $0(0 \%)$ & 0 & N/A & $1(0 \%)$ & 0 & $0 \%$ & $1(0 \%)$ & 0 & $0 \%$ \\
\hline Agaricia humilis & $U$ & $\mathrm{H}$ & $9(2 \%)$ & 4 & $44 \%$ & $8(1 \%)$ & 0 & $0 \%$ & $17(1 \%)$ & 4 & $24 \%$ \\
\hline Agaricia lamarcki & U & L & $2(0 \%)$ & 0 & $0 \%$ & $4(0 \%)$ & 0 & $0 \%$ & $6(0 \%)$ & 0 & $0 \%$ \\
\hline Agaricia species & U & L & $4(1 \%)$ & 0 & $0 \%$ & $6(1 \%)$ & 0 & $0 \%$ & $10(1 \%)$ & 0 & $0 \%$ \\
\hline Colpophyllia natans & $\mathrm{H}$ & $\mathrm{H}$ & $7(1 \%)$ & 6 & $86 \%$ & $2(0 \%)$ & 0 & $0 \%$ & $9(1 \%)$ & 6 & $67 \%$ \\
\hline Dendrogyra cylindrus & $\mathrm{H}$ & $\mathrm{H}$ & $2(0 \%)$ & 2 & $100 \%$ & $1(0 \%)$ & 0 & $0 \%$ & $3(0 \%)$ & 2 & $67 \%$ \\
\hline Dichocoenia stokesii & $\mathrm{H}$ & $\mathrm{H}$ & $7(1 \%)$ & 4 & $57 \%$ & $1(0 \%)$ & 0 & $0 \%$ & $8(1 \%)$ & 4 & $50 \%$ \\
\hline Diploria labyrinthiformis & $\mathrm{H}$ & $\mathrm{H}$ & $2(0 \%)$ & 1 & $50 \%$ & $2(0 \%)$ & 2 & $100 \%$ & $4(0 \%)$ & 3 & $75 \%$ \\
\hline Eusmilia fastigiata & $\mathrm{H}$ & 1 & $8(1 \%)$ & 2 & $25 \%$ & $0(0 \%)$ & 0 & $\mathrm{~N} / \mathrm{A}$ & $8(1 \%)$ & 2 & $25 \%$ \\
\hline Favia fragum & $U$ & $U$ & $0(0 \%)$ & 0 & N/A & $2(0 \%)$ & 0 & $0 \%$ & $2(0 \%)$ & 0 & $0 \%$ \\
\hline Helioseris cucullata & U & $U$ & $0(0 \%)$ & 0 & N/A & $4(0 \%)$ & 0 & $0 \%$ & $4(0 \%)$ & 0 & $0 \%$ \\
\hline Madracis aurentenra & $\mathrm{U}$ & $U$ & $0(0 \%)$ & 0 & N/A & $1(0 \%)$ & 0 & $0 \%$ & $1(0 \%)$ & 0 & $0 \%$ \\
\hline Madracis decactis & $u$ & $u$ & $0(0 \%)$ & 0 & N/A & $30(3 \%)$ & 0 & $0 \%$ & $30(2 \%)$ & 0 & $0 \%$ \\
\hline Manicina areolata & $u$ & $u$ & $0(0 \%)$ & 0 & N/A & $2(0 \%)$ & 0 & $0 \%$ & $2(0 \%)$ & 0 & $0 \%$ \\
\hline Meandrina meandrites & $\mathrm{H}$ & $\mathrm{H}$ & $5(1 \%)$ & 4 & $80 \%$ & $1(0 \%)$ & 0 & $0 \%$ & $6(0 \%)$ & 4 & $67 \%$ \\
\hline Montastraea cavernosa & 1 & I & $16(3 \%)$ & 6 & $38 \%$ & $13(2 \%)$ & 3 & $23 \%$ & $29(2 \%)$ & 9 & $31 \%$ \\
\hline Mycetophyllia ferox & $U$ & L & $1(0 \%)$ & 0 & $0 \%$ & $0(0 \%)$ & 0 & N/A & $1(0 \%)$ & 0 & $0 \%$ \\
\hline Orbicella annularis complex & U & L & $1(0 \%)$ & 0 & $0 \%$ & $24(3 \%)$ & 0 & $0 \%$ & $25(2 \%)$ & 0 & $0 \%$ \\
\hline Orbicella annularis & 1 & L & $11(2 \%)$ & 1 & $9 \%$ & $22(3 \%)$ & 2 & $9 \%$ & $33(2 \%)$ & 3 & $9 \%$ \\
\hline Orbicella faveolata & 1 & । & $50(9 \%)$ & 12 & $24 \%$ & $61(7 \%)$ & 2 & $3 \%$ & $111(8 \%)$ & 14 & $13 \%$ \\
\hline Orbicella franksi & 1 & । & $10(2 \%)$ & 2 & $20 \%$ & $94(11 \%)$ & 1 & $1 \%$ & $104(7 \%)$ & 3 & $3 \%$ \\
\hline Orbicella species & U & $u$ & $0(0 \%)$ & 0 & N/A & $1(0 \%)$ & 0 & $0 \%$ & $1(0 \%)$ & 0 & $0 \%$ \\
\hline Porites astreoides & $\mathrm{L}$ & L & $143(25 \%)$ & 2 & $1 \%$ & 275 (32\%) & 0 & $0 \%$ & 418 (29\%) & 2 & $0 \%$ \\
\hline Porites porites & $\mathrm{L}$ & L & $62(11 \%)$ & 1 & $2 \%$ & $68(8 \%)$ & 0 & $0 \%$ & $130(9 \%)$ & 1 & $1 \%$ \\
\hline Porites species & $U$ & $u$ & $0(0 \%)$ & 0 & $\mathrm{~N} / \mathrm{A}$ & $4(0 \%)$ & 0 & $0 \%$ & $4(0 \%)$ & 0 & $0 \%$ \\
\hline Pseudodiploria clivosa & $\mathrm{H}$ & $U$ & $0(0 \%)$ & 0 & N/A & $2(0 \%)$ & 0 & $0 \%$ & $2(0 \%)$ & 0 & $0 \%$ \\
\hline Pseudodiploria strigosa & $\mathrm{H}$ & $\mathrm{H}$ & $9(2 \%)$ & 5 & $56 \%$ & $6(1 \%)$ & 1 & $17 \%$ & $15(1 \%)$ & 6 & $40 \%$ \\
\hline Siderastrea radians & $u$ & L & $27(5 \%)$ & 0 & $0 \%$ & $26(3 \%)$ & 0 & $0 \%$ & $53(4 \%)$ & 0 & $0 \%$ \\
\hline Siderastrea siderea & 1 & L & $148(25 \%)$ & 23 & $16 \%$ & $102(12 \%)$ & 20 & $20 \%$ & $250(17 \%)$ & 43 & $17 \%$ \\
\hline Solenastrea bournoni & 1 & $u$ & $0(0 \%)$ & 0 & N/A & $3(0 \%)$ & 0 & $0 \%$ & $3(0 \%)$ & 0 & $0 \%$ \\
\hline Stephanocoenia intersepta & 1 & L & $20(3 \%)$ & 1 & $5 \%$ & $22(3 \%)$ & 0 & $0 \%$ & $42(3 \%)$ & 1 & $2 \%$ \\
\hline
\end{tabular}

For Susceptibility: H, High; I, Intermediate; L, Low; U, Unknown. Relative abundance (X\%) of each species by zone is seen in the number of corals column; values were raised to the nearest whole value. 


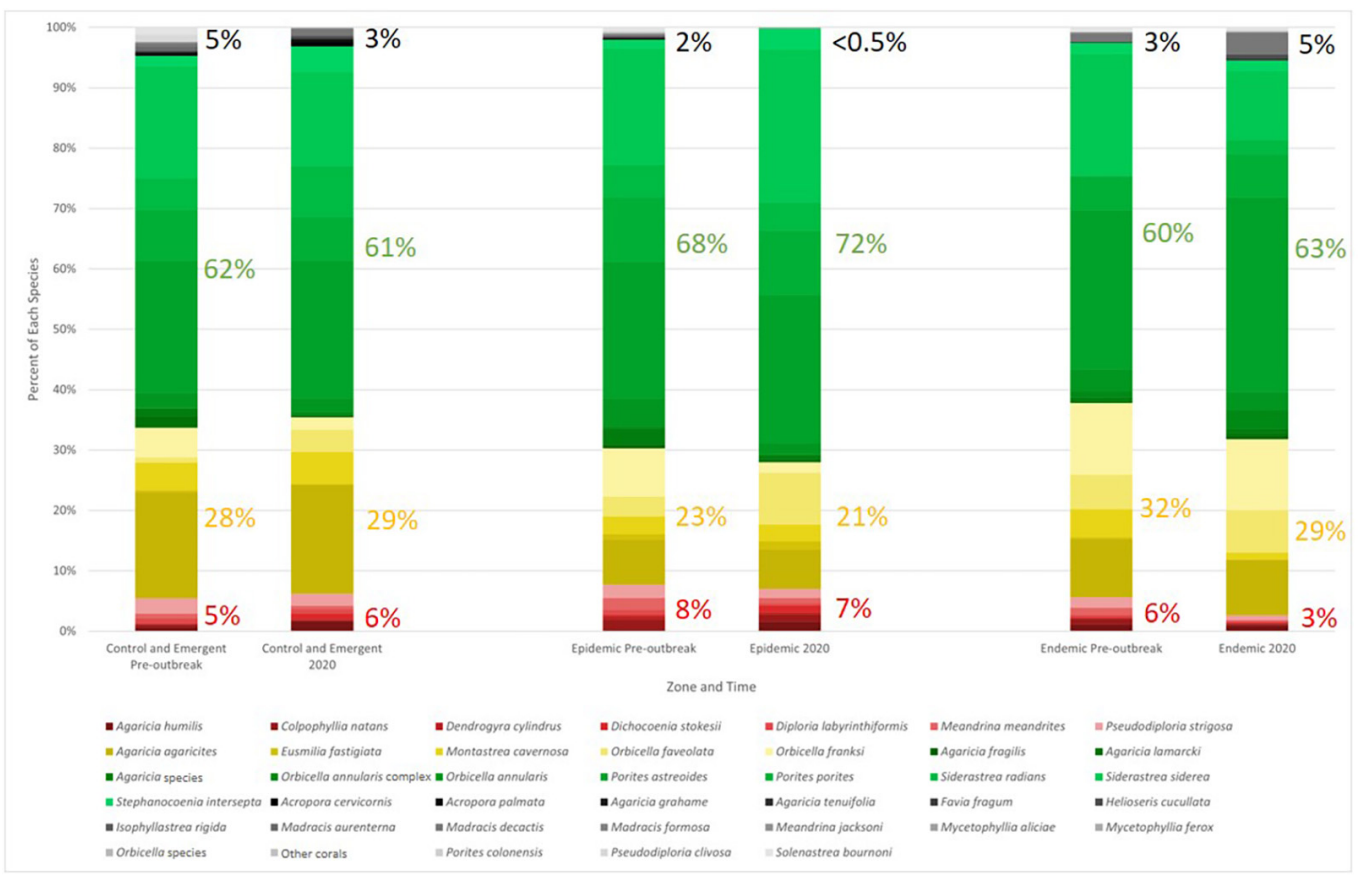

FIGURE 9 | Relative percent community composition by numbers of colonies of each coral species in the zone both pre-outbreak and in 2020 . Highly susceptible species are shown in reds, intermediate susceptible species in yellows, low susceptible species in greens, and unknown in grays. Percentages for each of these groupings are shown to the right of the corresponding bar and were rounded to the nearest whole number. Susceptibility classifications are based on the results from this study.

where disease prevalence rapidly increased until July when it appeared to plateau (Sharp et al., 2020b). This suggests that some surveys in this study could have been either too early or too late to find prevalence representative of the diversity and disease relationship. The importance of survey timing should be considered in future studies to analyze the relationship between disease prevalence and diversity. With strategic timing around peak prevalence, more significant positive relationships between SCTLD prevalence and coral diversity may be discovered and provide additional support that SCTLD does not follow the diversity-disease hypothesis. Finding the relationship between disease and diversity may heavily depend on when surveys occur.

\section{Impacts of Stony Coral Tissue Loss Disease}

This study found that more diverse sites suffered higher diversity loss but less coral cover decline, indicating that rare species were lost. This was most evident in the endemic zone, where SCTLD was present for at least 9 months. Rare species (ex. Colpophyllia natans, Dendrogyra cylindrus, and Madracis spp.) are more vulnerable to localized eradication because they are less represented at each site, therefore, they more to diversity than coral cover. These species were eliminated once SCTLD appears at a site, resulting in a noticeable decline in diversity. However, any change in coral cover was less detectable because rare species did not contribute heavily to benthic composition.
Within the endemic zone, coral cover loss was higher at less diverse sites but can be explained by the dominance of highly susceptible species at those sites. Pre-outbreak surveys have shown that species-poor sites had a higher proportion of highly susceptible species, making them more vulnerable to SCTLD impacts on coral cover. Highly susceptible species that drove coral cover loss at species-poor sites include Dichocoenia stokesii and Meandrina spp. These species within the endemic zone, saw decline exclusively at species-poor sites but not at speciesrich sites. Dichocoenia stokesii was not found in endemic zone benthic surveys at species-rich sites and Meandrina spp. was found only once.

Though the results of the ANOSIM were not significant, trends suggest that only the endemic zone saw changes in community composition between years. This heightens confidence that the trends observed regarding SCTLD impacts in the endemic zone are due to disease rather than differences in years. This could indicate that SCTLD has changed community composition within the endemic zone.

While we saw changes in community composition, they were not associated with changes in coral cover, though Sharp et al. (2020a) found that SCTLD may affect corals based on size. They modeled SCTLD transmission in the Florida Keys and found that SCTLD transmission was not dependent on coral density nor proximity to infected corals. Instead probability of contracting SCTLD appeared to be positively related to colony surface area (Sharp et al., 2020a). Therefore, we would expect coral cover in the endemic zone to significantly decrease from 
pre-outbreak to 2020 due to a loss of mainly large corals that contribute significantly to coral cover. However, our results show the opposite: that while corals were lost, this loss did not significantly alter coral cover.

\section{Susceptibility}

In the USVI, SCTLD prevalence on individual coral species indicates that disease susceptibility may differ from previous studies in other affected regions (SCTLD Case Definition, 2018). Some co-occurring species (E. fastigiata, O. annularis, S. siderea, and $S$. intersepta) in our study were assigned lower susceptibility classifications than in Florida (Table 1). Additionally, numerous other species (A. agaricites, A. fragilis, A. humilis, A. lamarcki, $M$. ferox, and $S$. radians) previously had unknown susceptibility, but were classified in this study (Table 1), providing important new information for scientists and managers. There were no instances where we observed a higher susceptibility classification than was observed in Florida, suggesting that our results may be conservative (SCTLD Case Definition, 2018). Confidence in the species susceptibility was determined by the total number of individual coral colonies surveyed (Supplementary Table 1).

Within the endemic zone, there was a dramatic loss of highly susceptible species. There was a decline or stasis from pre-outbreak to 2020 in all highly susceptible species. As susceptible (both highly and intermediate) species decreased, this zone saw an increase of low and unknown susceptible species. This drastic decline of highly susceptible species in the endemic zone foreshadows a detrimental species loss in the current epidemic zone. Additionally, due to SCTLD being present at sites in St. Thomas, USVI for only a year or less during the time of this study, it is unknown how the disease will affect diverse reefs that have more rare and susceptible species over longer time frames. We predict that as SCTLD continues to progress, it will considerably alter community composition of coral reef ecosystems due to the primary effects on reef building coral species, and therefore cause cascading changes in reef productivity throughout the Caribbean region.

\section{Broader Impacts}

Mean prevalence of SCTLD was $4.5 \%$ within the endemic zone and reached $17.7 \%$ in the epidemic zone. In comparison RuizMoreno et al. (2012) found a regional baseline disease prevalence of $1.8 \%$ for all diseases in nearby Puerto Rico from 2005 to 2007. Additionally, Weil (2004) monitored total disease prevalence of nine locations within the wider Caribbean region from 1999 to 2002 and reported a mean overall disease prevalence of $5.28 \%$. When comparing SCTLD to other diseases in the Caribbean, the notably high prevalence demonstrates just how broadly the disease is impacting coral reefs, as this study found in the endemic zone disease prevalence was nearly triple the prevalence recorded in previous studies within the area.

Therefore, due to the rapid and lethal impact of SCTLD on coral colonies, monitoring and mitigation should be prioritized, particularly for ESA-listed, highly susceptible, and rare species. Results from our study indicate that these aforementioned species are at great risk for loss across the northern USVI, especially within highly diverse reef ecosystems. Therefore, early detection is critical on corals within the USVI and wider Caribbean region. The establishment of rapid detection and response programs is suggested across the Caribbean with the complete capacity for initial disease identification, ongoing monitoring, and disease treatment. Once SCTLD is detected, rare and endangered species should be prioritized for treatment. Additionally, outplanting both severely threatened and resilient species should be heavily implemented in an effort to protect and maintain coral populations and reef composition. Much is still unknown regarding this disease and its long-term impacts on coral reef ecosystems. Future research should continue monitoring impacted sites where the disease has been present for an extended period of time. This information will also inform management on the longevity of this disease on reefs. Additional research should examine how species composition in one location determines the overall spread and longevity of the disease when sites are at peak prevalence. This information is vital in the mitigation of SCTLD and the survival of coral reefs within the greater Caribbean.

\section{DATA AVAILABILITY STATEMENT}

The original contributions presented in the study are included in the article/Supplementary Material, further inquiries can be directed to the corresponding author/s.

\section{AUTHOR CONTRIBUTIONS}

SC, SH, DO, KB, AL, SM, MM, KV, CC, MC, AS, MS, TS, and $\mathrm{MB}$ carried out the fieldwork. SC, $\mathrm{SH}$, and $\mathrm{DO}$ did the statistical analysis and performed the editing. SC, SH, DO, KB, $\mathrm{AL}, \mathrm{SM}, \mathrm{MM}, \mathrm{KV}$, TS, JB, and $\mathrm{MB}$ did the data management. CC performed the map configuration. SC, SH, DO, KB, AL, MM, $\mathrm{KV}, \mathrm{CC}, \mathrm{MC}, \mathrm{AS}$, and MS did writing. SC, SH, DO, KB, AL, SM, $\mathrm{MM}, \mathrm{KV}, \mathrm{KG}, \mathrm{RP}, \mathrm{TS}, \mathrm{JB}$, and MB made the revisions. All authors contributed to experimental design.

\section{FUNDING}

This work was supported by the National Science Foundation (Biological Oceanography) award \#1928753 to $\mathrm{MB}$ and TS, VI EPSCoR (NSF \#0814417), and the Territorial Coral Reef Monitoring Program funded by the USVI Department of Planning and Natural Resources, Division of Coastal Zone Management and the NOAA Coral Reef Conservation Program (\#NA17NOS4820033).

\section{ACKNOWLEDGMENTS}

We would like to thank the University of the Virgin Islands Master of Marine and Environmental Science (MMES) program for providing the means and opportunity to complete this project. Specifically, Sophia McKenzie and Joseph Townsend for providing any support and resources necessary during the duration of this 2020 Capstone project. We would additionally 
like to thank the UVI technical diving team, Rosmin Ennis, Adam Glahn, and Sarah Heidmann, who assisted on survey dives and captaining vessels during fieldwork days. Finally, we would like to thank Christopher Stubbs for providing support in the creation of the map.

\section{REFERENCES}

Aeby, G. S., Bourne, D. G., Wilson, B., and Work, T. M. (2011). Coral diversity and the severity of disease outbreaks: a cross-regional comparison of acropora white syndrome in a species-rich region (American Samoa) with a speciespoor region (Northwestern Hawai'ian Islands). J. Mar. Biol. 2011, 1-8. doi: $10.1155 / 2011 / 490198$

Aeby, G. S., Ushijima, B., Campbell, J. E., Jones, S., Williams, G. J., Meyer, J. L., et al. (2019). Pathogenesis of a tissue loss disease affecting multiple sections of corals along the florida reef tract. Front. Marine Sci. 6:678. doi: 10.3389/fmars.2019. 00678

Alvarez-Filip, L., Estrada-Saldívar, N., Pérez-Cervantes, E., Molina-Hernández, A., and González-Barrios, F. J. (2019). A rapid spread of the stony coral tissue loss disease outbreak in the mexican caribbean. PeerJ 7, 1-17. doi: 10.7287/peerj. preprints.27893v1

Aronson, R. B., and Precht, W. F. (2001). White-band disease and the changing face of Caribbean coral reefs. Hydrobiologia 460, 25-38. doi: 10.1023/A: 1013103928980

Civitello, D. J., Cohen, J., Fatima, H., Halstead, N. T., Liriano, J., McMahon, T. A., et al. (2015). Biodiversity inhibits parasites: broad evidence for the dilution effect. Proc. Natl Acad. Sci.U.S.A. 112, 8667-8671. doi: 10.1073/pnas. 1506279112

Dahlgren, C. (2020). Rapid Assessment of the Occurrence of Stony Coral Tissue Loss Disease (SCTLD) Along the Southern Coast of Grand Bahama, Bahamas.Ph, D. Thises. Florida: Jupiter.

Gilbert, G. S., and Sousa, W. P. (2002). Host specialization among wood-decay polypore fungi in a Caribbean mangrove forest. Biotropica 34, 396-404. doi: 10.1111/j.1744-7429.2002.tb00553.x

Gintert, B. E., Precht, W. F., Fura, R., Rogers, K., Rice, M., Precht, L. L., et al. (2019). Regional coral disease outbreak overwhelms impacts from a local dredge project. Env. Mon. Assess. 19:630. doi: 10.1007/s10661-019-7767-7

Gochfield, D. J., Olson, J. B., Chaves-Fonnegra, A., Smith, T. B., Ennis, R. S., and Brandt, M. B. (2020). Impacts of hurricanes irma and maria on coral reef sponge communities in St. Thomas, U.S. Virgin Islands. Estuar. Coasts 43, 1235-1247. doi: 10.1007/s12237-020-00694-4

Green, E. P., and Bruckner, A. W. (2000). The significance of coral disease epizootiology for coral reef conservation. Biol. Conser. 96, 347-361. doi: 10. 1016/s0006-3207(00)00073-2

Haas, S. E., Hooten, M. B., Rizzo, D. M., and Meentemeyer, R. K. (2011). Forest species diversity reduces disease risk in a generalist plant pathogen invasion. Ecol. Lett. 14, 1108-1116. doi: 10.1111/j.1461-0248.2011.01679.x

Huang, Z. Y. X., Van Langevelde, F., Estrada-PeÑa, A., Suzan, G., and De Boer, W. F. (2016). The diversity-disease relationship: evidence for and criticisms of the dilution effects. Parasitology 1, 1-12. doi: 10.1017/S0031182016000536

Jackson, J. B. C., Donovan, M. K., Cramer, K. L., and Lam, V. V. (2014). Status and Trends of Caribbean Coral Reefs: 1970-2012. Switzerland: Global Coral Reef Monitoring Network, IUCN.

Keesing, F., Holt, R. D., and Ostfeld, R. S. (2006). Effects of species diversity on disease risk. Ecol. Lett. 9, 485-498. doi: 10.1111/j.1461-0248.2006.00885.x

Kramer, P. R., Roth, L., and Lang, J. (2020). Map of Stony Coral Tissue Loss Disease Outbreak in the Caribbean. Available online at: https://www.agrra.org/coraldisease-outbreak/ (accessed March 13, 2020).

Miller, J., Muller, E., Rogers, C., Waara, R., Atkinson, A., Whelan, K. R. T., et al. (2009). Coral disease following massive bleaching in 2005 causes $60 \%$ decline in coral cover on reefs in the US Virgin Islands. Coral. Reefs 28:925. doi: 10.1007/s00338-009-0531-7

Miller, M. W., Karazsia, J., Groves, C. E., Griffin, S., Moore, T., Wilber, P., et al. (2016). Detecting sedimentation impacts to coral reefs resulting from dredging the Port of Miami. Florida USA. PeerJ 4, 1-19. doi: 10.7717/peerj.2711

\section{SUPPLEMENTARY MATERIAL}

The Supplementary Material for this article can be found online at: https://www.frontiersin.org/articles/10.3389/fmars. 2021.682688/full\#supplementary-material

Mitchell, C. E., Tilman, D., and Groth, J. V. (2002). Effects of grassland plant species diversity, abundance, and composition on foliar fungal disease. Ecology 83, 1713-1726. doi: 10.1890/0012-9658

Muller, E. M., and van Woesik, R. (2012). Caribbean coral diseases: primary transmission or secondary infection? Glo. Change Biol. 18, 3529-3535. doi: $10.1111 /$ gcb.12019

Muller, E. M., Sartor, C., Alcaraz, N. I., and van Woesik, R. (2020). Spatial epidemiology of the stony coral tissue loss disease in Florida. Front. Mar. Biol. 7:163. doi: $10.3389 /$ fmars. 2020.00163

National Centers for Coastal Ocean Science (NCCOS) and Southeast Fisheries Science Center (SEFSC). (2018). National Coral Reef Monitoring Program: Assessment of Coral Reef Benthic Communities in the U.S. Virgin Islands from 2017-06-12 to 2017-08-04 (NCEI Accession 0176081). NOAA National Centers for Environmental Information. Dataset. https://www.ncei.noaa.gov/archive/accession/017608. (accessed January 20, 2020).

National Centers for Coastal Ocean Science (NCCOS) and Southeast Fisheries Science Center (SEFSC). (2020). National Coral Reef Monitoring Program: Assessment of Coral Reef Benthic Communities in the U.S. Virgin Islands from 2019-06-08 to 2019-08-09 (NCEI Accession 0215460). NOAA National Centers for Environmental Information. Dataset. https://www.ncei.noaa.gov/archive/ accession/0215460 (accessed January 20, 2020).

Noaa Coral Reef Watch. (2020). NOAA Coral Reef Watch Version 3.1 Dail Virgin Islands 5-km Satellite Coral Bleaching Degree Heating Week Product, College Park, Maryland, USA: NOAA Coral Reef Watch. Available online at: https: //coralreefwatch.noaa.gov/product/vs/data/usvi.txt (accessed May 22, 2020).

Pollock, F. J., Morris, P. J., Willis, B. L., and Bourne, D. G. (2011). The urgent need for robust coral disease diagnostics. PLoS Pathogens 7:e1002183. doi: 10.1371/ journal.ppat.1002183

Precht, W. F., Gintert, B. E., Robbart, M. L., Fura, R., and van Woesik, R. (2016). Unprecedented disease-related coral mortality in Southeastern Florida. Sci. Rep. 6, 1-11. doi: 10.1038/srep31374

R Core Team. (2019). R: A Language and Environment for Statistical Computing. Vienna: R Foundation for Statistical Computing.

Ruiz-Moreno, D., Willis, B. L., Page, A. C., Weil, E., Cróquer, A., Vargas-Angel, B., et al. (2012). Global coral disease prevalence associated with sea temperature anomalies and local factors. Dis. Aquat. Organ. 100, 249-261. doi: 10.3354/ dao02488

SCTLD Case Definition. (2018). Florida Coral Disease Response Research \& Epidemiology Team. Available online at: https://floridadep.gov/sites/default/ files/Copy\%20of\%20StonyCoralTissueLossDisease_CaseDefinition\%20final\% 2010022018.pdf (accessed January 12, 2020).

Sharp, W. C., Shea, C. P., Maxwell, K. E., Muller, E. M., and Hunt, J. H. (2020a). Evaluating the small-scale epidemiology of the stony coral tissue loss disease in the middle Florida Keys. PLoS One 15:e0241871. doi: 10.1371/journal.pone. 0241871

Sharp, W., Maxwell, K., Smith, K., and Hunt, J. (2020b). Investigating the Ongoing Coral Disease Outbreak in the Florida Keys: Continued SCTLD Monitoring at Middle and Lower Florida Keys, experimental Coral Restoration of SCTLDSusceptible Coral Species, and Assessing the Prevalence of SCTLD on Intermediate Reef Habitat. Florida: Florida Fish \& Wildlife Conservation Commission Fish \& Wildlife Research Institute, 1-24.

Smith, T. B., Brandt, M. E., Calnan, J. M., Nemeth, R. S., Blondeau, J., Kadison, E., et al. (2013). Convergent mortality responses of Caribbean coral species to seawater warming. Ecosphere 4:87. doi: 10.1890/ES13-00107.1

Smith, T. B., Ennis, R., Kadison, E., Nemeth, R. S., and Henderson, L. M. (2017). The United States Virgin Islands Territorial Coral Reef Monitoring Program. 2017 Annual Report. United States Virgin Islands: University of the Virgin Islands, 295. 
Staletovich, J. (2020). Ballast Water Could Be Driving the Spread of Devastating Coral Disease. WLRN, Miami, South Florida. Available online at: https://www. wlrn.org/post/ballast-water-could-be-driving-spread-devastating-coral-diseas e?mc_cid=db87476cec\&mc_eid=752ba29057\&fbclid=IwAR2VmyigbDtST-m _ Y29sAd-BqHMfuRLgwsNVLTHhz9hfvPJPTdEo5awFea4\#stream/0 (accessed March 20, 2020).

Sutherland, K. P., Porter, J. W., and Torres, C. (2004). Disease and immunity in caribbean and indo-pacific zooxanthellate corals. Mar. Ecol. Prog. Ser. 266, 273-302. doi: 10.3354/meps07531

Virgin Islands Coral Disease Advisory Committee VI-CDAC. (2020). Available online at: https://www.vicoraldisease.org/ (accessed January 20, 2020).

Walton, C., Hayes, N. K., and Gilliam, D. S. (2018). Impacts of a regional, multi-year, multi-species coral disease outbreak in Southeast Florida. Front. Mar. Sci. 5:323-337. 10.3389/fmars.2018. 00323

Ward, J. R., Rypien, K. L., Bruno, J. F., Harvell, C. D., Jordan-Dahlgren, E., Mullen, K. M., et al. (2006). Coral diversity and disease in Mexico. Dis. Aquat. Organ. 69, 23-31. doi: 10.3354/dao069023
Weil, E., and Rogers, C. S. (2011). "Coral reef diseases in the atlantic-caribbean," in Coral Reefs: An Ecosystem in Transition, eds Z. Dubinsky and N. Stambler (Netherlands: Springer), doi: 10.1007/978-94-007-014-4_27

Weil, E. (2004). "Coral reef diseases in the wider Caribbean". in Coral health and disease (pp. 35-68. Springer, Berlin, Heidelberg. (accessed January 26, 2021).

Conflict of Interest: The authors declare that the research was conducted in the absence of any commercial or financial relationships that could be construed as a potential conflict of interest.

Copyright (c) 2021 Costa, Hibberts, Olive, Budd, Long, Meiling, Miller, Vaughn, Carrión, Cohen, Savage, Souza, Buckley, Grimes, Platenberg, Smith, Blondeau and Brandt. This is an open-access article distributed under the terms of the Creative Commons Attribution License (CC BY). The use, distribution or reproduction in other forums is permitted, provided the original author(s) and the copyright owner(s) are credited and that the original publication in this journal is cited, in accordance with accepted academic practice. No use, distribution or reproduction is permitted which does not comply with these terms. 